\title{
METAPHORS AND LEGAL LANGUAGE: A FEW COMMENTS ON ORDINARY, SPECIALISED AND LEGAL MEANING
}

\author{
SYLWIA WOJTCZAK \\ University of Lodz \\ swojtczak@wpia.uni.lodz.pl \\ IWONA WITCZAK-PLISIECKA \\ University of Lodz \\ iwona.plisiecka@uni.lodz.pl
}

\begin{abstract}
The present text offers a few comments on the metaphorical dimension of legal language and the nature of legal language as such. The authors discuss selected metaphors in the context of the Polish legislation with the aim to show how the metaphorical dimension of language can be used and abused. It is also demonstrated that the metaphorical dimension of language can cross-cut the interface between language and law on different levels. There are metaphors in legal texts that can be deliberately used to emphasise or cover selected aspects of meaning, and others that can just happen to act irrespective of any premeditated action on the part of the legislator. Finally, in a wider perspective, it is shown that the relation between ordinary language and the language of the law, i.e. ordinary meaning and legal meaning, may itself be seen as a relation between two domains within which metaphorical mapping takes place. It is claimed that the divide between the realm of law and the "real world" goes beyond a trivial division relative to expertise in the law and expertise in legal discourse, but can be better understood as the division between the legal community and the non-legal community including the academia where linguists reside.
\end{abstract}

Keywords: legal language, metaphor, law, LSP

\section{Introduction}

Despite the common belief that the language of the law is a variety characterised by a high level of explicitness, law, being a product of culture, is itself metaphorical in nature. The concepts of law, even the simplest ones, such as that of the "legal person" or "crime", draw on metaphorical imagery and involve metaphor-related processes which can be seen as important in the course of legal interpretation and (sometimes) visible, or made explicit, on the level of drafting the law. In such contexts it is particularly interesting that there seems to be a gap between how lawyers, on the one hand, and lay people, on the other, understand 
the nature of law and legal texts, with lawyers often explicitly denying that the texts may at all be phrased in a (or in fact "any") metaphorical way.

In this paper we want to discuss selected metaphors exploited first of all in the context of the Polish legislation with the aim to show how the metaphorical dimension of language can be used, and in some cases even abused, to project a favourable image of a legal concept in question, and sometimes to blur or reshape its conceptualisation. We would also like to show that the metaphorical dimension of language can cross-cut the interface between language and law on different levels. There are particular metaphors which are present and operate within legal texts and such metaphors can be deliberately used to emphasise or cover selected aspects of meaning, or can just happen to act irrespective of any premeditated action on the part of the legislator. In a much wider perspective, the divide between ordinary language and the law (phrased in legal language), may itself be seen as a borderline across which semantic mapping takes place. It is this divide between the legal meaning and the ordinary meaning that we would like to emphasise as we believe it does not simply correspond to what linguists see as the divide between "legal language-oriented meaning" and "ordinary meaning". We claim that the firm, yet invisible, divide between the realm of the law and the so-called "real world" goes beyond a simple division marked by people with higher expertise in legal language, and folk people; it is primarily relevant for the division between the legal community and the non-legal community including the academia where linguists reside.

In other words, having accepted the fact that language as a phenomenon is metaphorical in nature, on the basis of the examples presented below we will try to address the question of the role of metaphoricity in legal contexts, which may go beyond the typical way in which it is perceived in much linguistic theorising. The discussion presented here is based on the data retrieved and analysed while working on the project financed by the Polish National Science Centre: "Metaphor as a mechanism to understand language of law and legal language and to experience law (quoting examples of Polish legal language)". ${ }^{1}$

Following a general cognitive approach we would like to defend three main theses, which can be summarised as follows:

1. All terms that the legislator has used in a legal text have legal meaning;

2. Even when the reader interprets legal language as having either ordinary (or specialised) meaning, or a meaning similar to the ordinary (or specialised) meaning, he or she can do it just because the legislator has allowed such interpretation as it is the legislator that holds power over the creation of legal norms encoded in the text.

3. When the reader accepts the ordinary (or specialised) meaning for a legal language word or a phrase, or disambiguates (or makes more precise) the

\footnotetext{
${ }^{1}$ Pol. "Metafora jako mechanizm rozumienia języka prawnego i prawniczego oraz doświadczania prawa na przykładzie polskiego języka prawnego i prawniczego," directed by Sylwia Wojtczak, Department of Law and Administration, University of Lodz, Poland (OSF, ID 220257, 2013/09/B/HS5/02529).
} 
ordinary (or specialised) meaning and gives it to a legal language word or phrase, in effect, he or she uses a metaphor whose target domain is a legal concept and the source domain is an ordinary (or, respectively, specialised) concept.

In the following sections we will clarify the above-listed points.

\section{Theoretical background and methodological assumptions}

The approach to metaphor that is accepted for the present study is directly associated with the cognitive theory of metaphor in the tradition of Lakoff and Johnson (1980/2003; Lakoff 1987) and the general cognitive linguistics approach where linguistic meaning is perceived as inherently metaphorical, naturally perspectival, dynamic (cf. e.g. Geeraerts 2006, 2007, Fauconnier 1997), and embodied (e.g. Lakoff \& Johnson 1999).

It is worth noting that although the interface of cognitive metaphor studies and legal studies is still a relatively novel and largely uncharted territory, next to the language and law area, metaphor-oriented research programmes have already become well established in various other linguistic interfaces, such as language and economics, mathematics, politics, ethics, etc ${ }^{2}$.

In a cognitive perspective metaphor is an omnipresent element of human categorisation, a predominant tool thanks to which people may organise their thoughts about the world, both in its physical and social aspects. In the process of categorisation people form concepts, which can be understood as "a heterogeneous sets of knowledge representations" (cf. Machery 2005) ${ }^{3}$. Our linguistic image of the world is thus a function of metaphorical categorisation of the world's various aspects and emerges in a largely organized way across semantic fields, which can be easily illustrated with Lakoff and Johnson's (1980/2003) much-quoted examples of metaphorical concepts such as TIME IS

\footnotetext{
${ }^{2}$ There are numerous metaphor-oriented publications that concentrate on the psychological aspects of communication (e.g. Gibbs 1994, 2008); there are also many researchers that focus on diachronic issues (e.g. Sweetser 1990, Geeraerts 1997, Blank \& Koch 1999), on linguistics and performativity (Sweetser 2001, Witczak-Plisiecka 2007), on literary aspects (e.g. Turner 2006, Lakoff \& Turner 1989), different sign systems which include sign language (Taub 2001), on rhetoric (e.g. Turner 1987), ethics (Johnson 1993), politics (Goatly 2007), mathematics (Lakoff \& Núñez 2000), economics (e.g. Herrera-Soler \& White 2012), as well as the links between metaphor and emotions (Kövecses 2000) and intercultural contexts (cf. Kövecses 2015 and the literature cited within).

${ }^{3}$ Machery's psychological definition may be accepted here, but it is worth noticing that there is some confusion with regard to the use of metalinguistic labels such as "concept", "conception", "conceptualization". As these lexemes are notoriously polysemous (and on occasion may be ambiguous); in the present paper we use the word "concept" to refer to a mental representation without further internal distinctions; "conceptualization" is used to refer to the process of thinking by which a person builds a concept, and "conception", similarly to "concept", can be identified with a thought, although we try to avoid using the term in relation to metaphorical concepts (such as ARGUMENT IS WAR) not to invite further confusion.
} 
MONEY and ARGUMENT IS WAR. Selected examples belonging to these concepts have been quoted below as (1) and (2):

(1) TIME IS MONEY

You're wasting my time.

This gadget will save you hours.

How do you spend your time these days?

That flat tire cost me an hour. I've invested a lot of time in her.

I don't have enough time to spare for that.

You're running out of time.

You need to budget your time.

Put aside some time for ping pong.

Is that worth your while?

He's living on borrowed time.

You don't use your time profitably.

Thank you for your time.

(quoted after Lakoff \& Johnson 1980: 7-8)

(2) ARGUMENT IS WAR

Your claims are indefensible.

He attacked every weak point in my argument.

His criticisms were right on target.

I demolished his argument.

I've never won an argument with him.

You disagree? Okay, shoot!

If you use that strategy, he'll wipe you out.

He shot down all of my arguments.

(quoted after Lakoff \& Johnson 1980: 4)

The examples above serve to show that there is systematicity in metaphorical mapping between the source and the target domains involved in either of the concepts. The integration of two such domains is not random, but motivated and assists people in organising a consistent picture of the world. Repeated use of sentences and utterances which realize such metaphorical concepts function as invitation to (re)conceptualizing, for instance, arguments in terms of war, or time in terms of money. In legal contexts this natural process can sometimes be seen as a problem, can be exploited with a hidden agenda, or just be present in a neutral way. In ordinary language, while talking about, e.g. economy, people may invite different perspectives by evoking conceptualisations resulting in metaphors of the type: ECONOMY IS A FLOWER, ECONOMY IS FIRE, ECONOMY IS MACHINE, etc. In a similar manner, selective use of metaphorical imagery in the law may invite a preferred conceptualisation, or may sometimes lead to abusing the law. Even the legislator may choose to use terms that suggest ordinary (lay) 
meaning with a particular pragmatic agenda, for instance to hide legal meaning from lay audiences, ${ }^{4}$ or to produce grounds for future modifications.

To reiterate, in accord with cognitive linguistics we accept that language is inherently metaphorical, that there is no clear-cut and principled borderline between literal and metaphorical uses of language. We further accept that in general language can be treated as a reflection of how its users make sense of the world. However, the fact that language is a metaphorical phenomenon in its entirety has only partial relevance for our study, in which we are interested in metaphors as present in the legal professional contexts and in the interface between legal language and ordinary language. We believe that metaphor is not just a rhetorical decorative device, along with synecdoche, hyperbole, litotes, etc., and that it can be found informative in various perspectives. Metaphorical mechanisms provide a foundation for language as such, then, on a more mundane level, imagery present in language reflects contemporary and past conceptualisations of worldly phenomena. Such imagery is often so fossilised that it is hard to see its metaphorical dimension without effort. On a more sophisticated level, imagery may be created so that to invite predefined and preferred conceptualisations, to create rather than to reflect. In specialised professional contexts users will often naturally create imagery which is semantically restricted and whose meaning is more easily accessible (or only accessible) to the community in question. In the realm of law it does not have to be the case that the legislator wants to manipulate or mislead the interpreter; however, legal semantics is necessarily constrained by the legal system, which provides a frame for its signification.

For the purposes of the present study, we understand legal language as the language of the legislation, legal interpretation, and professional legal debates 5 . It needs to be emphasised that this "kind" of legal language cannot be readily identified with "legal language" as an LSP, i.e. a language for a specific purpose described in linguistics literature, where it is characterised with reference to the qualitative and quantitative features which, in the case of legal English, make it different from English at large. Among the characteristics of the English legal language understood as such a subdomain there are, e.g., the presence of

\footnotetext{
4 There are widely quoted examples of terms which appear often but may possess unique professional definitions within a system, e.g. the legal system, cf. "consideration" as used in contract law, or "determine" as used in the judicial context. Going beyond the level of the lexeme may produce further difficulties. Not long ago in Poland there was a lot of discussion related to "renovation and modernization" of buildings and flats whose costs the owners could take off their income tax. At some point, tax office authorities attempted to force a narrow interpretation of the phrase quoting definitions from outside tax law, viz. using construction law terminology. However, the judiciary opposed such interpretation and followed a wide, dictionary-oriented, definition of the phrase.

${ }^{5}$ In Polish, following Wróblewski's $(1948,1984)$ ideas, there is typically a distinction drawn between legal language in the sense of the language of legal documents (język prawny) and legal language as used in lawyer-client communication (jezyk prawniczy). This difference is not given a theoretical status in the present discussion.
} 
technical vocabulary (whether directly recognised as "legal" or having specialised meaning within the domain ${ }^{6}$ ), the presence of vocabulary that may be seen as archaic (e.g. deictics such as: hereintofore, thereto), of Norman-French relicts, Latin words and phrases (e.g. bona fide, sub judice), doublets and triplets (e.g. give, devise and bequeath, aid and abait, null and void), in English - the use of the deontic "shall", etc. (cf. Mellinkoff $1963^{7}$ ). Among typically quoted characteristics there are also features of style such as decontextualisation and vagueness which allows for application in a variety of contexts (cf. Endicott 2000, Gibbons 1994, Gotti 2003, Danet 1980, 1985, Williams 2005, WitczakPlisiecka 2007). In general, legal varieties are marked as formal and relatively non-transparent for ordinary people who have not been trained in the law. While we recognise that such characteristics are relevant especially for the language of legal documents, we want to stress that legal semantics is even more complex and "treacherous". A closer analysis of how legal interpretation works indicates that the fact that many words that appear "common" have specialised meaning within the system of the law is just the beginning as in fact all words and phrases relevant for legal institutions are semantically restricted and the language of the law is a language apart in a very special sense.

\section{Legal metaphors - selected "simple" examples}

In our theorising about legal metaphors we would like to present selected "simple" cases where metaphors serve to cover certain actions or turn out to be obsolete in the context of technological advancements. The first discussed case focuses on the present concept of the juristic person in the Polish law, the other, in a more explicit way, shows how past conceptualisations of legal concepts may hamper the legal process.

It is common knowledge that metaphors emphasise and foreground certain aspects, while simultaneously covering others. This mechanism has evidently been exploited in the Polish Act of 28 Oct 2002 on Criminal Liability of Collective Entities for Punishable Offences [Pol. "Ustawa z dnia 28 października o odpowiedzialności podmiotów zbiorowych za czyny zagrożone pod groźbą kary"], whose Polish title significantly does not expose the word "criminal" as an attribute ${ }^{8}$.

\footnotetext{
${ }^{6}$ For instance, the word „consideration” is common in English, but has a special technical meaning within the law of contract.

${ }^{7}$ Over the years there has grown an enormous body of literature on the subject including plain language movement contributions offering guidelines for "improvements" (cf. Williams 2005 and references within), but Mellinkoff's text (1963) was one of the first comprehensive descriptions of legal language conceived as a sublanguage.

${ }^{8}$ The fact that the word "criminal" is not present in the title does not of course mean that it is covered that the Act belongs in the criminal law, but its absence can be read as a conscious act to avoid exposing the contentious concept next to that of "collective entities".
} 
In a legal perspective there are three coordinates of a legal concept: the relevant legal system, the historical moment, and the branch of the law in which the concept belongs. In Poland, whose legal tradition is to a large extent convergent with the German system, the concept of the juristic person belongs in the field of civil law, while the concept of criminal liability is a concept of criminal law. This tradition finds its reflection in the legal paroemia, a maxim recognised as a rule in the Polish legal tradition: Societas delinquere non potest, which means that guilt can (only) be attributed to a (real, physical) person as society cannot commit a crime; as a result there should never be corporate criminal responsibility. Thus, in the Polish legal system the two concepts, criminal liability and corporate subjects, had not been directly linked. However, the need to harmonize the Polish law with European Union law necessitated convergence of the two within the criminal law system.

Faced with a conflict between the European Union law and the Polish legal tradition, the legislator employed a strategy in which they used a mixture of metaphorical images throughout the Act. The images correspond to various theoretical conceptions of the juristic person, which were found relevant for particular parts of the Act.

There exist a number of theories of the juristic person in the law, including theories of fiction and realistic theories. Within the realistic theories there are theories of personal equivalent: 1) organic theories and 2) theories of aggregated person. Within the theories of non-personal equivalent there are: 1) theories of prescribed property; 2) theories of collective property; and 3) theories of collective interest and collective aim. Following the images that relate to the above-mentioned theories, a juristic person can be understood as "fictitious", as "an object", "the whole (organism)", "property" (cf. collective interest or aim). The juristic person can also have the image of a real human being, of a living being (not necessarily human), an aggregate of elements, or of a group of people. In short, it is expected that just one theory should be accepted and applied in a particular context. However, the Act on Criminal Liability of Collective Entities does not show a uniform imagery, but a patchwork of images coming from different legal conceptualisations.

There are numerous passages where the juristic person is presented in terms of a (real) person, a human being whose attributes include: being responsible (cf. Art. 1, Art.3, Art.5); being able to experience financial (or other, e.g. psychological) gain and loss, such as being subject to financial sanctions (Art. 3, Art. 7, Art. 8, Art. 10, Art. 11; Art. 12); having wealth (Art. 8); being capable of exercising due diligence, or negligence (Art. 3, Art. 5); having (personal) reputation (that may suffer as a result of malpractice) (Art. 10); being able to "improve" morally and in law-oriented performance (Art. 10); being able to cooperate with other 'juristic persons' (Art. 3); being able to appoint representatives, who act in the entity's interest (Art. 3, Art. 5, Art. 10), etc.; being able to bear sanctions and prohibitions (Art. 9). Further images that emerge from the Act reveal the relative indeterminacy of the nature of 
"collective entities". For instance, the juristic person can be presented as a manmade object (Art.2), a collection of physical beings (Art. 11, 16, 2), or as property (Art. 5). The procedural part of the Act is significantly different from the substantial part and shows collective entities in terms of actual collective bodies.

It may be assumed that the heterogeneity of images present in the Act is indicative of varied concepts of collective subjects which are correlated with the legislator's varied purposes; at least some of the images serve to cover the "foreign" concept of the juristic person in the context of corporate liability.

It is worth noting that until 2002 there had been a principle that only a human being can be a subject to criminal law and when the Act on Criminal Liability appeared in 2002, it stirred a heated debate which led to its being sent for examination by the Polish Constitutional Tribunal. The Constitutional Tribunal examined the Act following the requests of various business organisations and expressed some reservations which then led to certain modifications in the Act. However, significantly, the Constitutional Tribunal officially declared that the model of liability imposed by the Act is not criminal liability sensu stricto, and that the liability is "not primary", but "secondary and derivative" (Pol. "odpowiedzialność wtórna i pochodna"). At the same time the Constitutional Tribunal asserted that it was liability of repressive character, thus in effect "criminal" in the constitutional terms.

It seems that both the legislator and the Constitutional Tribunal struggled with the images of the juristic person at the same time trying to be pragmatic in their actions. The images must have appeared rather naturally as functions of the underlying metaphorical conceptualizations. The legislator avoided addressing the issue of the nature of the juristic person, which in reality could mean a call for constitutional changes, modifying relevant images so that the Act induced as little resistance and criticism as it was possible at the time. The Constitutional Tribunal, on the other hand, suggested a solution in which the "secondary" and "derivative" liability was able to fit in the Polish legal tradition without the need to modify the Constitution.

Evidently, both the Constitutional Tribunal and earlier the Polish legislator had to fight with well-established metaphorical imagery which turned out to be at least partially obsolete. It may also be claimed that the pragmatic adjustment was able to overrule at least some of such metaphoric imagery (e.g. asserting the image that there are criminal liabilities sensu stricto and secondary, derivative ones) and, in effect, much of the local legal doctrine.

There are numerous examples of metaphorical images present in legislation which can be misleading in the context of interpreting the law. An illustrative case of interlinguistic relevance is provided by Larsson (2011) with reference to the concept of theft and copyright of digital publications.

The traditional image of stealing involves the scenario of taking another person's property without permission or legal right, and without intending to return "the object". However, "modern" theft, for instance theft of digitalised 
data, does not necessarily involve removing an object from a place and relocating. Instead, the more relevant image will be that of copying, multiplying, spreading, etc. In such contexts there emerge difficulties in applying the law phrased in accordance with the old imagery. In fact the "old" image will often exert so much impact that it may be difficult to "see" copying as theft. The metaphorical image of stealing is simply mistaken and inadequate in such new contexts, but remains influential and pervasive, giving rise to a kind of semantic illusion.

A similar point can be raised with reference to other cases of persistent metaphorical images that can hamper proper applications of the law. In the Polish contexts, there have been disputes with regard to, e.g. "white plastics" and "piercing the corporate vail" (cf. Wojtczak et al. 2017, pp. 287f.). In the "white plastics" appellate case the judgment involved the concept of forgery. The case was focused on actions which included using "white plastics" for stealing money. The central issue was whether using the plastic cards, which in their appearance were much different from original credit and debit cards, could ever be identified with using forged bank cards. The party who were found guilty of forgery by the court of first instance claimed that the "white plastics" that had been used were not "good enough examples" in terms of forgery to be classified as such. The dispute involved the metaphorical concept FORGERY IS IMITATION, which was further developed to include an imitation as an object which "imitates", i.e. looks like the original one. The court, however, adopted a different perspective pointing to the fact that THE ORIGINAL IS A PERFECT ITEM, but an imitation is a "worse", less perfect object and can be "incomplete". It followed that in the court's interpretation forged items were always "worse" than the original. In the discussion that followed the court indicated that while an original bank card was in fact a piece of plastic whose characteristics included a graphic representation of the owner's and the bank's name, the most important characteristic was the function which such a card performed. In conclusion the image of "white plastics" as items which being imperfect could never be judged as forged credit and debit cards was overruled. The court decided that forging means creating imperfect items and that "white plastics" were used to perform functions ascribed to genuine bank cards. It is notable that the discussion in the case was focused on linguistic imagery directly relevant for metaphor-oriented analysis.

In the other case mentioned, the image of "piercing the corporate vail" was used by the court to elucidate the court's actions. The case involved a situation in which technically there were two cooperating companies. However, it was found that the companies employed the same workers and assigned to them the same responsibilities. The forming of two companies had been motivated by profits which the companies were able to draw from the fact that they did not have to pay extra hours and other benefits to their employees who on the surface divided their work hours between the two employers. Finally, in using the

${ }^{9}$ Cf. Verdict of the Polish Supreme Court of 17 March 2015; reg. no. I PK 179/14. 
concept of "piercing the corporate vail" to refer to the exposition of the unlawful action, the court implicitly asserted that companies may be "vailed" and covered or "divided". Moreover, the court indicated that the companies" action was not "complete"; the court "pierced" the "veil" only in the areas (at the "knots") which were relevant for the case in question.

In summary, the metaphorical imagery discussed in the present section involves presenting one concept in terms of another either as a result of past processes of conceptualisation, or in order to project a desired conceptualisation. In the following sections a more contentious claim is raised, the claim that in the legal context there is a consistent metaphorical mapping between ordinary language and legal language, i.e. the language which is "turned" on legal institutions.

\section{4. "Legal meaning" - the first approximation}

Let us start the discussion of "legal meaning" with the first thesis requoted in an extended form.

Thesis no. 1:

All terms used by the legislator in a legal text have legal meanings:

1) this holds true irrespective of the fact whether the text in question sounds as if it belongs in everyday, i.e. lay people's, language (language at large, or - as lawyers would put it - casual, ordinary language) or is an explicit specialized language (LSP), and;

2 ) it is the case even though there are interpretation rules which may promote ordinary meaning or emphasise situated recognition of specialised meaning ${ }^{10}$, and which would sometimes send the reader to ordinary language interpretation or specialized language interpretation.

As a Polish legal theoretician, Jerzy Wróblewski, claimed back in 1959:

The relation between terms used in legal regulations and the cognate (identical) terms as used in ordinary language boils down to either accepting ordinary meaning, or to making the term more precise as needed for a proper application of the law, or, finally, to giving the term a new meaning, which significantly diverges from its ordinary application ${ }^{11}$.

\footnotetext{
${ }^{10}$ It is emphasised in the Polish legal system, as in many others, that "[a] norm should be assigned a plain ordinary meaning unless there are important reasons to divert from such meaning" [Pol. "Normie należy przypisać takie znaczenie, jakie ma ona w języku potocznym, chyba że ważne względy przemawiają za odstąpieniem od tego znaczenia.”] (Morawski 2002: 118).

11 Pol: „Stosunek znaczeń terminów używanych w przepisach prawnych do znaczeń równobrzmiących zwrotów $\mathrm{w}$ potocznym ich użyciu polega bądź na przyjęciu znaczenia potocznego, bądź na pewnym jego uściśleniu potrzebnym do właściwego stosowania prawa, bądź wreszcie na nadaniu terminowi znaczenia w wydatnym stopniu odbiegającego od potocznego użycia wyrazu" (Wróblewski 1959: 215, emphasis added).
} 
What Wróblewski originally commented on was legal interpretation (Pol. "wykładnia prawa"), which naturally related his considerations to the field of the reader's actions. He explicitly says that the reader "accepts", "disambiguates", "makes", or "gives" meaning. However, it must be borne in mind, and seems quite explicit for lawyers, that what the reader does follows the legislator's prior actions performed on the legal text in the process of its drafting. This follows from the fact that, especially within statutory law (Pol. "prawo stanowione"), it is the legislator that should be the source of the meaning of the legal text.

Thus (and here comes thesis no. 2), even when the reader interprets legal expressions as having ordinary meaning, or a meaning similar to their ordinary meaning, he or she can do it just because the legislator has allowed such interpretation as it is the legislator that holds power over the creation of legal norms encoded in the text. Similarly, when the reader interprets legal expressions as having specialized meaning, or a meaning similar to specialized meaning, he or she can do it within the space granted to him or her by the legislator. It follows that the meaning that the reader "gives" to the text is neither ordinary meaning, nor specialized meaning, but just and only "legal" meaning. Such legal meaning may just happen to be similar to, or identical with, ordinary meaning; it may also just happen to be similar to, or identical with, the relevant specialised meaning.

In effect, expressions within legal language always have legal meaning(s). It may just be the case that such legal meanings may coincide, at the legislator's will, with ordinary, or specialized, meaning to a certain degree. Whether or not a legal text includes typical attributes of legalese (e.g. semantically restricted terms of art, definitions which determine certain concepts, e.g. a commensurate, contextual definition, an implicit definition, etc.), the meaning which resides in such a text is "legal" meaning, and such legal meaning (not identical with what is recognised as specialised meaning in most linguistics practice) should be sought in case of any dispute.

Significantly, a similar perspective on legal meaning can be found in the theory put forward by a German lawyer Arthur Kaufmann, who years before the cognitive turn claimed that legal concepts are inherently analogical and as such "make it possible to transfer the language of our observable world to the realm of psychic and intellectual life" (Kaufmann 1966: 382). Kaufmann further elucidated legal interpretation pointing to the fact that "inter-pretatio" means literally an appraising mediation, a settling of the right mean" (Kaufmann 1966: 363). Pointing to the fact that all human cognition starts with sense perception, Kaufmann warned against identifying intellectual concepts with their perceptual elements. In his opinion, matters which are beyond sense experience can only be expressed through analogical concepts and "virtually all juristic concepts, even the so-called descriptive ones, are analogical concepts, because they never express a meaning which is merely perceptional but always (at least 
additionally) an intellectual, a specifically legal meaning" (Kaufmann 1966: $382)$.

It is notable that Kaufamnn's reflection on analogical concepts can be identified with later discussions offered by Gentner (e.g. Gentner et al. 2001), who points to the convergence of metaphor and analogy, with analogy being the basic mechanism of cognition, but also of legal reasoning.

In conclusion it appears that the claim that "legal meaning" is a meaning apart from what linguistics recognise as semantic, pragmatic, specialised, LSPbased meaning, etc. is well grounded in both legal theory and partially in cognitive studies. Evidently, what is needed is a deeper insight and more integration between the two disciplines.

\section{Legal meaning in practice - a case study}

The question of legal meaning can be illustrated with the verdict of the Appellate Court in Katowice, Poland, of 2 June 2011, reg. no. II AKa 142/11, which was focused on the meaning of the phrase "with extreme cruelty" (Pol. "ze szczególnym okrucieństwem"; in literal translation: "with particular cruelty").

The facts of the case were as follows: By the decision of 27 December 2010, the District Court in Cz. found A.K. guilty of: a) mental cruelty afflicted on his wife - J.K. - during the period between September 2006 and 28 September 2009, when he would initiate verbal fights and address the wife with vulgar, offensive language; b) physical abuse which included beating the wife all over her body with a poker or a stick, throwing furniture and other objects at her, pulling her hair, pushing her around, strangling, pouring cold water over her body, and keeping her under water to cause suffocation; c) causing physical injury as a result of an attack of 25 September 2009, which involved numerous bruises and internal hematomas. The final attack was recognised as an action under Art $207 \S 1$ of the Polish Criminal Code (PCC henceforth ) associated with Art. 157 \$2 Of PCC with 11 \$2 PCC; as a result the Court sentenced the man to 18 months imprisonment.

With the same verdict the Court determined that over the same period of time, deliberately, repeatedly, with the use of violence and verbal abuse including life threats, A.K. forced his wife - J.K. - to perform and suffer sexual activities which included serious abuse, for which the Court sentenced him to 24 months imprisonment.

Based on Art. 85 and $86 \$ 1$ PCC, the Court decided to administer the total penalty of three years imprisonment, recognising detention time (of three months) as part of the imprisonment to be served.

Both parties in the case in question, i.e. the defendant's lawyer, and the prosecutor, appealed against the Court decision. The defence claimed that: a) there was abuse of process (Art. 4, 7, 410, and $424 \S 1$ PCC) as the reasoning of the court was based solely on evidence for the prosecution and on quite 
uncritical acceptance of the victim's testimony despite the fact that evidence gathered during proceedings provided grounds for the assumption that the victim had misinterpreted some of the defendant's actions as instances of ill-treatment and abuse, and there was no sufficient justification for accepting the actions as ill-treatment in the judgment under appeal; b) the facts of the case were misrepresented and negatively influenced the judgment under appeal, viz. it had been accepted without sufficient evidence that in the context of sexual contacts, the defendant had abused the victim acting with physical violence and that the victim had expressed her protest against an intercourse with the defendant.

Pointing to the above-mentioned claims, the defence demanded that the judgement under appeal should be modified in its first part (point I) and reversed in the second part (point II). The first modification would mean administration of a milder penalty, while the second would mean acquitting the defendant, or, alternatively, remanding the decision and sending the case for re-trial.

The prosecution also appealed against the judgement presenting the following claims:

a) there was an abuse of substantive law (Art. 197 \$2 PCC) in the form of misinterpretation of the Article, as a result of which the defendant's behaviour, which included forcing the victim through physical abuse and unlawful threats to engage in oral intercourse, was classified only as an act under Art 197 \$2 PCC, while in reality such an act is a surrogate of an act of copulation and is classified as other forms of sexual intercourse falling under Art. $197 \S 1$ PCC; the faulty linguistic form of the description of the act was also indicated;

b) the facts of the case on which the judgment was based were misrepresented by erroneously accepting that the defendant's behaviour including pushing his fist or a towel into the victim's vagina solely constituted an act of causing sexual intercourse and could be classified as "a rather regular sexual behaviour" without giving any indication of deviant sexual practices on the part of the defendant, while in reality such patterns of behaviour on the part of the defendant were marked with particular cruelty;

c) there was abuse of process (Art. $8 \S 1$, Art. 7 PCC, Art. $193 \S 3$, and 194) with negative impact on the final judgement by resolving factual and legal matters being of essential importance for the case, viz. determining whether the defendant's behaviour was to be identified as marked with particular cruelty, on the basis of oral expert opinion given by a psychiatrist and a sexologist;

d) there was abuse of process (Art. $424 \S 1$ point 2 PCC) with negative impact on the final judgement by misapplication of the Article and failure to provide full and logical argumentation relating to the reasoning of the court and in particular explaining why the court decided to use the negative interpretation of Art. 197 §4 PCC; 
e) there emerged glaring incommensurability of penalties administered for the defendant for individual acts, and consequently, gross incommensurability of the total penalty being a three-year imprisonment.

Referring to the above-mentioned claims, the prosecution demanded that the verdict be reversed with regard to point II and remanded with regard to point I, or, alternatively, modified by giving a three-year sentence, and a six-year sentence for acts under point I and II respectively, and giving a total sentence of seven years imprisonment.

The Appellate Court in Katowice, Criminal Law Division, having reviewed the case, having considered relevant facts of the case and the verdict given by the court of first instance, decided to remand the case pointing to erroneous judgments in point II, III, and IV, i.e. the verdict with regard to the total penalty administered, and including the time of pre-sentence detention within the length of the imprisonment according to the final sentence. The court decided to affirm the lower verdict in other aspects with one exception, viz. recognising the time of actual imprisonment of the defendant as time served with regard to the sentence. In addition, the court decided that the defendant would have to cover the costs of the appellate court proceedings.

In the context of the present discussion the most crucial point in the reported case was the Court's discussion of the phrase "with extreme/particular cruelty". Giving the verdict, the Appellate Court explicitly indicated that even if the term (in this case the phrase "with extreme cruelty") had not been given a definition by the legislator, and, as a result, it might seem that its meaning is its everyday meaning, there was no other person but the court that could provide guidance as to how this term was to be interpreted because such an opinion is "an opinion about the law". Asserting that a culprit acted "with extreme cruelty" is "a legal assessment of the action"; the court emphasised that not even an expert psychiatrist or a sex therapist could have given relevant opinion on the meaning of "with extreme cruelty" in a legal context and that the court was not supposed to just follow an opinion given by such a person. It was stressed that the meaning of the legal language phrase (here: "with extreme cruelty") had to be determined by the court alone. In a case where there was no legal definition, the meaning should be determined on the basis of its use, i.e. relevant tradition, relevant history in legal theory, legal interpretation and previous court decisions. It was also indicated as regular practice that giving grounds for the final judgment the Appellate Court would normally quote variants of meaning relevant for the expression under discussion.

It is thus the case that if a certain legal language item has no legal definition, for instance an equal definition, a contextual definition, an implicit definition, or other, the doctrine and prior court decisions serve as guidance and help establish the meaning of such an item with reference to ordinary meaning, or specialized meaning given by experts. The lawyers would import from ordinary or specialized meaning what in their opinion is of greatest significance in terms of values and norms applied by law in general or by a specific legal norm relevant 
for the context in question. However, they are not supposed to uncritically follow either ordinary meaning or expert opinion.

Reconsidering the situation of this particular case it is clear that the phrase "with extreme cruelty" was used in the context of the proceedings by all parties and by witnesses invited to give their more or less professional opinions. The persons, both physical and legal, or collective, who contributed with their perspective on its semantics included: 1) the legislator, 2) the victim, 3) the expert-witness sexologist, 4) the defence lawyer, 5) the prosecution, and 6) the judge, i.e. finally "the court".

In general, the legislator's meaning, as encoded in the written law, is necessarily decontextualised to a certain degree to allow for a general application of legal provisions in numerous contexts which remain unspecified at the time of enacting or drafting of the law. Thus, even in contexts where the noscitu a sociis, or the ejusdem generis rule is applied, quite naturally a finite list of particular patterns of behaviour that would exhaust the category cannot be provided. In the case under analysis the victim's recognition of "extreme cruelty" in the context of law is by definition seen as a lay opinion, which does not need to match the legal understanding of the term. What may be more surprising for lay people without legal training is the fact that the expert witnesses' opinion falls on the same side, i.e. that a witness expert sexologist is not a good enough source of determining the limits of "extreme cruelty". However, in this context it may be instructive to see that there have been more astonishing and explicit clashes between "legal" and "scientific" semantics in the past, including judgements recognising snails as "inland fish", carrot as "fruit", or tomatoes as "vegetables", albeit evidently for commercial reasons ${ }^{12}$. It is thus interesting not only how legal interpretation diverges from lay people's interpretations, but also how it may diverge within the legal circle.

In the process of determining the meaning of "with extreme cruelty" in the case in question, the court enumerated the concepts of "extreme cruelty" as present in the legal doctrine. It was asserted that "interpretation of the said phrase may be done on various levels and with the stress on selected elements of the case"13. Following the first of the concepts of rape, the stress is on the assessment of the harm done as a result of the action, such as physical harm and the resulting mental trouble, a line of interpretation that can also be seen in other legal cases ${ }^{14}$. According to the second concept, cruelty should be measured as

\footnotetext{
${ }^{12}$ The above-mentioned cases included judgements which concerned practical life issues, such as equalling subsidies for fisheries with that those for snail farms, allowing the use of the label "jam" for traditional Portuguese carrot "jam" in the European Union, and the level of taxes on tomatoes brought to the United States (cf. Witczak-Plisiecka 2013 for a brief discussion of the cases).

${ }^{13} \mathrm{Cf}$. resumée of the court's reasoning included in the case brief; the verdict of the Appellate Court in Katowice, Poland, of 2 June 2011, reg. no. II AKa 142/11; LEX (Polish legal database) no. 1001359.

${ }^{14}$ Cf. e.g. the judgment by the Polish Supreme Court of 5 March 1974, registered as III KR 399/73, OSNKW 1974, no. 6, p. 113; cf also comments by Falandysz in Prawo karne. Czesść szczególna [Criminal Law: Case Studies], Warszawa 1970, p. 59.
} 
relative to the intensity of resistance on the part of the alleged victim. In other words, unless the rapist's means and actions were not "proportional" to the resistance exhibited by the victim, the rape can be determined as performed with "extreme cruelty". The line of reasoning visible in the third concept emphasizes the necessity to determine the alleged rapist's particular intent in committing the crime. Extreme cruelty can be the case when the rapist's intent, beyond the plan to have a sexual intercourse, includes the aim of humiliating his victim, of causing pain, etc ${ }^{16}$. Finally, the fourth concept defines extreme cruelty with reference to the means employed by the rapist, to the types of particular actions that he performs within the act ${ }^{17}$. In the corpus of the Supreme Court's decisions one may also find instances of an eclectic approach, which blends various concepts ${ }^{18}$.

It is also worth mentioning that there are laws which steer the interpretation of "extreme cruelty" with reference to the victim and the victim's personal characteristics. Thus, following the Polish Supreme Court's reasoning (cf. fn. 19 below), to act with "extreme cruelty" may be identified with a rape against a minor or immature person, e.g. a child, especially where the perpetrator, being aware of the possible consequences of his action, the consequences in the form of a psychological shock, physical damage of the victim's organs, or other forms of trauma, intentionally executes his act with a vengeance ${ }^{19}$.

Taking a closer look at the metaphorical imagery that can be found in the above-mentioned concepts of "extreme cruelty," as evidently construed and eventually used by the court, we may notice the following:

1. In the first concept there is a metaphorical mapping with focussing on the notion of a substantial physical discomfort or negative psychological consequences of the deed on the part of the victim. While emphasising "discomfort" this kind of conceptualisation "hides" other elements present in the lay image of a rape scenario, such as the rapist's intention to cause pain. "Focussing" as used here is supposed to be a natural process widely discussed in literature (e.g. Jäkel 2002: 22 on religious metaphors), descriptive of the process by which metaphors naturally supply only a partial picture or explanation of the target domain and will always highlight selected aspects, while simultaneously hide others.

2. In the second concept metaphorical mappings focus on the proportional relation, on the "ratio" between the victim's resistance and the means

\footnotetext{
${ }^{15}$ Cf. the verdict by the Polish Supreme Court of 9 April 1971, Polish Supreme Court Bulletin [Pol. Biuletyn SN] 1971, no. 6.

${ }^{16}$ Cf. the verdict by the Polish Supreme Court of 2 November 1971, Polish Supreme Court Bulletin [Biuletyn SN] 1971, no. 12.

${ }^{17}$ Cf. comments given by M. Filar on the Polish Supreme Court's judgment of 5 March 1974, PiP [Państwo i Prawo; Eng. "State and Law"] 1975/2.

${ }^{18}$ Cf. the Polish Supreme Court's guidelines of 1972 (VI KZP 64/72, OSNKW 1973, no. 2-3, point 18 and W. Radecki (1972): Przestępstwa przeciwko wolności w sferze życia seksualnego [Offences against freedom in sexual life], Vol. II, Prob. Praw. 1972, no. 5-6, p. 30.

${ }^{19}$ Cf. Stępień (2000) on special cruelty as a mark of the crime of aggravated rape.
} 
employed by the perpetrator; in order to characterise the deed as performed with extreme cruelty, the resistance and the means must be "disproportionately intense". The mapping in this concept hides other selected elements present in the lay conceptualisation of the rape, such as physical harm, mental harm, causing pain intentionally, etc.

3. Application of the third concept leads to focussing on a particular intent on the part of the rapist, i.e. on the person's deliberate plan to cause humiliation to the victim and to cause pain. It also hides common elements of the rape scenario such as physical or psychological harm, etc.

4. Application of the fourth concept results in "highlighting" the rapist's means and the type of his action, but it simultaneously hides common elements of the rape scenario such as physical or psychological harm, intent to cause pain, etc.

5. The fifth concept is not a simple collective entity, not just a sum of all elements of the lay understanding of "extreme/particular cruelty". It still is a result of focussing, albeit a more eclectic one.

6. The sixth concept in its metaphorical mapping focuses on the victim's properties, in particular on these properties and features that make the victim particularly susceptible to pain, suffering and trauma. By exposing these elements, this representation hides and neglects other aspects, some of which are foregrounded in the other conceptualisations as indicated above.

It is in light of the exposition of the varied conceptualisations of "extreme cruelty" as shown above that we would like to raise the final hypothesis and claim that the linguistic interface of legal and lay community involves metaphorical mapping between language at large and legal language, which (at least party) mirrors the divide between the realm of law and the "real", ordinary world $^{20}$. This is a kind of mapping in which lay understanding of the legal semantics is usually not in accord with the legal view and only occasionally can prove accurate. As has been shown above, metaphorical imagery of the discussed concept within the law is varied, but first of all it never really matches or even involves the full common image either of "rape" or of "extreme cruelty". In the following section we will propose an approximation of the legal-lay language metaphorical relation hypothesis.

\footnotetext{
${ }^{20}$ A related, albeit more critical, point has been raised by Hutton (1995), who suggests that law "belongs to the world", while linguistics is just an academic discipline. His point is that law regulates legal and social relations in the world, while linguistics tends to refer to itself rather than to some extra-linguistic (independent) reality. In effect, in order to comment on the nature of language linguists would focus on language as an autonomous code disregarding much of the social context crucial to the law. In a still more critical way, Hutton (1995: 295) points out that linguistics, being an academic discipline, is unique in that linguists communicate within their group, while other academics may find experts in their field "outside" their domain. In his words, "[linguists] are not professional experts: their professional standards and professional knowledge are largely discipline-internal" (Hutton 1996: 295).
} 


\section{Legal meaning - the metaphorical perspective revisited}

Let us present thesis no. 3 which builds on Wróblewski's (1959) way of reasoning as cited above:

When the reader accepts ordinary (or specialised) meaning for a legal language item, or disambiguates (makes more precise) ordinary (or specialised) meaning and gives it to a legal language item, in effect, he or she uses a metaphor whose target domain is a legal concept and the source domain is an ordinary (or, respectively, specialised) concept.

We can trace this process on the basis of the quoted case by distinguishing two important domains: the domain of ordinary language and the domain of legal language. While expressing the metaphorical mapping:

EXTREME CRUELTY (in a legal sense) IS EXTREME CRUELTY (in ordinary, common sense)

we seemingly produce a tautology. However, the essence of this procedure is that, just as it is the case with all metaphors, between the legal concept of EXTREME CRUELTY and the common (or ordinary, as lawyers would say) concept of an identical form: EXTREME CRUELTY, there arises a relation of true metaphorical mapping with all its characteristic features, including the fact that the mapping is selective. The selectiveness involved in the images of "extreme cruelty" in the context of rape associated with particular legal conceptions of the notion has been discussed in the preceding section. The process that is present here mirrors natural selectiveness and exemplifies the focussing hypothesis, which are aspects of metaphors widely discussed in relevant literature (cf. Lakoff \& Johnson 1980/2003, Jäkel 2002). For instance, sentence (3) below

(3) This meeting cost me half of the day.

embodies metaphor TIME IS MONEY, but (4) below:

(4) The whole of my day broke into pieces.

points to the metaphor TIME IS A BRITTLE OBJECT, and focuses on a different aspect.

As noted above, "extreme cruelty" in the legal sense can only be determined within the legal domain and by legal experts. Its meaning belongs in the system of law and escapes lay understanding. Like many other seemingly vague terms, such as "due diligence", "safe speed", "mental cruelty" 21 , etc., "extreme cruelty" can have a precise shape not even by just reading it with due attention paid to the situational context in which it is rooted, but necessarily in the context of its

21 Cf. Witczak-Plisiecka 2008 and the citations within for a discussion of vagueness as against ambiguity in legal contexts. 
relevant legal system. Thus, it cannot be identified with its ordinary language counterpart whose form it only mirrors, and it cannot be identified with a specialised meaning of "extreme cruelty" as explicated in this particular case by an expert witness sexologist. Even expert opinion is an opinion from outside law and may prove useful, just as dictionaries will often prove useful in the courtroom, but such an opinion is not binding in the legal sense. It follows, and it finds its reflection in the law (cf. Art. 193 \$1 PCC), that expert witnesses can provide their expert opinion, but should never address the question of guilt, or attempt any judgment with regard the accused as this lays solely in the authority of the court. In the case under discussion the Appellate Court decided that offering judgement as to the accused's being guilty or not ("not" in this particular case), the expert witness moved beyond his competences as a witness in the proceedings. It was also determined that in following expert witness opinion, and using it in deciding the case, the court of first instance performed malpractice and transferred lay opinion into the area of adjudication and criminal law. It was explicitly indicated that the court of first instance should have reviewed the legal doctrine and history of adjudication where the phrase "extreme cruelty" was an issue and should have analysed the accused's deed against such background, instead of relying on expert witness testimony. It was also asserted that the doctrine and history of interpreting the phrase would normally invite a deep analysis across various dimensions and with accents put on various aspects of its use in the legal context.

It is evident that "legal meaning" to which the Appellate Court chose to refer, even though dynamic and underdetermined just as natural languages are, was something different from "ordinary meaning". It is that meaning that can be recognised as a product of the metaphorical mapping from ordinary language into legal language.

\section{Conclusions}

The discussion of selected aspects of legal semantics presented above invites the conclusion which can be phrased as thesis no. 4:

As legal language words, phrases and sentences are defined most frequently by either accepting entirely or disambiguating, i.e. making more precise, ordinary meaning, it follows that metaphorisation (in the form explained in thesis 3 ) is the basic instrument for categorization in the legal domain.

In legal contexts metaphorical mapping is present at different levels, but the most predominant mapping can be found in a wider social perspective between the realm of law with its semantics and language (including specialised languages) in the non-legal contexts. This seems to be in accordance both with legal theorising in Kaufmann's (1966) tradition and with a general cognitive perspective on metaphor. 
Certain additional comments are needed as the picture is more complex. For instance the "extreme cruelty" case discussed in this paper was judged at more than one court. After being considered in the court of first instance, it was taken to the appellate court for revision where it induced extended argument. In a simple picture where there are just two camps: lawyers and lay people, it might seem that there are only two relevant semantics systems, the legal semantics and the lay semantics. It follows that legal concepts, in this case the concept of "extreme cruelty", should receive just legal interpretation wherever and whenever such concepts are judged by lawyers. However, the dispute between the Appellate Court and the court of first instance all happened "within" the legal domain; there were no "outsiders" at that stage of the argument. Should that mean that the court of first instance was not able to recognise the (proper) meaning, i.e. the relevant metaphorisation? Or was the court simply ignorant and not proficient enough when it failed to recognise the relevant meaning?

The answer seems to be that although the macro picture of the metaphorical mapping between the legal domain and the ordinary language domain is correct, there are factors that affect the process of interpretation and, as a result, even within the legal domain it is not realistic to expect that we are able to secure identical, universally proper and relevant readings and applications of the law on all occasions.

First of all, lawyers differ in their expertise and diligence, which may lead to different results. As noted by Lakoff and Johnson with regard to all humankind (1982/2003: 5), "we act according to the way we conceive of things;" it follows that where the process of legal conceptualisation is not perfect people may experience difficulties. It is the case after all that when there are competing interpretations in a legal case, the final one is backed with clarifying reasoning, which explicates and justifies the verdict.

Another relevant point is that language, even within the legal domain, retains its natural features; it remains underdetermined and open textured. As Hart (1961: 128) pointed out,

we should not cherish, even as an ideal, the conception of a rule so detailed that the question whether it applied or not to a particular case was always settled in advance, and never involved, at the point of actual application, a fresh choice between open alternatives. [...] [T]he reason is that $[\ldots]$ we are men, not gods.

It should follow that within the legal camp we may expect a kind of striving for perfection. This perfection will partly be concerned with words, but there is also an underlying belief that language with its metaphorical dimension gives us an insight into ways in which human cognition works. Consequently, in the legal context we may expect that perfection is more directly connected with expertise beyond language, i.e. a kind of expertise in the realm where language functions as an underdetermined basic layer, but is only a part of the reality in the legal world. Thus, in many ways words are lawyers' only tools, but the reality in 
which legal practice belongs is more subtle than a general dictionary-based semantics.

Eventually, legal practice can be illustrated with another powerful, and a rather romantic metaphor commented on years ago by Jerome N. Frank (1947):

THE LEGISLATOR IS A COMPOSER

\section{THE INTERPRETING LAWYER IS A PERFORMING MUSICIAN}

\section{A NORMATIVE ACT IS A PIECE (OF MUSIC)}

In discussing his creative metaphor and citing the composer Ernst Křenek, Jerome Frank emphasises that the interpretation of a score may allow for a great number of equally good and satisfactory variants, while retaining fidelity. $\mathrm{He}$ further points to the fact that "the wise composer expects the performer to read his score 'with an insight that transcends' its 'literal meaning" (Frank 1947: 1262). This is clearly illustrative of what is the very essence in the hypothesis of metaphorical mapping between language at large and language of the law. Evidently, there may be better and worse "legal performers", but there is an expectation that performance should be accurate and that there is a meaning encoded by a "legislative composer" that goes beyond lay meaning and that what the legislative composer drafted should be read and applied in an efficient way.

In conclusion, it is worth reiterating that words are important in the law and metaphorisation is a basic instrument in both legal and lay communication and cognition. Legal language, being a professional variety, just like ordinary language remains underdetermined. It is a function of the legal system, but the image of the law encoded in language remains secondary with regard to the realm of law. Lawyers need to rely on their (legal) abstract system even though their disputes are phrased in what appears natural language and may often involve "ordinary", i.e. lay people. As can be seen in the cases mentioned above, in professional practice lawyers must cope with both language dynamicity and the fact that the legal system is constantly evolving as in both spheres there is constant motion. Thus, even though legal discussions of plain meaning might have their merits by e.g. promoting clarity, argumentation skills, etc., and should not be eradicated, it is of utmost importance to recognise that legal meaning cannot be readily identified with plain meaning, or even with what linguists call specialised meaning. To explain the relation between legal meaning and ordinary meaning, and consequently between legal language and common language, with the image of metaphorical mapping between two different domains appears to be a sound hypothesis which provides an illustrative explanation for the difference in question. 


\section{References}

Blank, Andreas \& Peter Koch (eds.) 1999. Historical Semantics and Cognition. Berlin: Mouton de Gruyter. https://doi.org/10.1515/9783110804195

Danet, Brenda. 1980. "Language in the legal process". Law and Society Review 14, pp. 445-564. https://www.jstor.org/stable/i354491; https://doi.org/10.2307/3053192.

Danet, Brenda. 1985. "Legal discourse". In: Handbook of Discourse Analysis, ed. by Teun Van Dijk. New York: Academic Press, pp. 273-291.

Endicott, Timothy A.O. 2000. Vagueness in Law. Oxford: Oxford University Press. https://doi.org/10.1093/acprof:oso/9780198268406.001.0001

Falandysz, Lech. 1970. Prawo karne: Część szczególna [Criminal Law: Case Studies], Warsaw.

Fauconnier, Gilles 1997. Mappings in Thought and Language. Cambridge: Cambridge University Press. https://doi.org/10.1017/CBO9781139174220

Frank, Jerome N. 1947. "Words and music: Some remarks on statutory interpretation". Columbia Law Review. No. 8, pp. 1259-1278. https://doi.org/10.2307/1118098

Geeraerts, Dirk. 1997. Diachronic Prototype Semantics: A Contribution to Historical Lexicology. Oxford: Clarendon Press.

Geeraerts, Dirk (ed.) 2006. Cognitive Linguistics: Basic Readings. Berlin: Walter deGruyter. https://doi.org/10.1515/9783110199901

Geeraerts, Dirk \& Hubert Cuyckens (eds.) (2007) The Oxford Handbook of Cognitive Linguistics. Oxford: Oxford University Press.

Gentner, Dedre, Brian F. Bowdle, Phillip Wolff, Consuelo Boronat. 2001. "Metaphor is like an Analogy" In: The Analogical Mind: Perspectives from cognitive science, ed. by D. Gentner, K.J. Holyoak, \& B.N. Kokinov. Cambridge, Mass.: MIT Press, pp. 199-253. https://doi.org/10.7551/mitpress/1251.001.0001

Gibbons, John (ed.) 1994. Language and the Law. London: Longman.

Gibbs, Raymond W. Jr. 1994. The Poetics of Mind: Figurative Thought, Language, and Understanding. Cambridge: Cambridge University Press.

Gibbs, Raymond W. Jr. (ed.) 2008. The Cambridge Handbook of Metaphor and Thought. Cambridge/New York: Cambridge University Press.

https://doi.org/10.1017/CBO9780511816802

Goatly, Andrew 2007. Washing the Brain: Metaphor and Hidden Ideology. Amsterdam: John Benjamins Publishing Company. https://doi.org/10.1075/dapsac.23

Gotti, Maurizio. 2003. Specialised Discourse. Linguistic Features and Changing Conventions. Bern et al.: Peter Lang.

Hart, H. L. A. 1961/1994. The Concept of Law (2nd ed.). Oxford/New York: Clarendon Press.

Herrera-Soler, Honesto \& Michael White (eds.) (2012) Metaphor and Mills: Figurative Language in Business and Economics. Berlin/Boston: De Gruyter Mouton. https://doi.org/10.1515/9783110274585

Hutton, Christopher. 1995. 'Law lessons for linguists? Accountability and acts of professional communication', Language and Communication 16(3): 205-14. https://doi.org/10.1016/02715309(96)00010-9

Jäkel, Olaf. 2002. "Hypotheses revisited: The cognitive theory of metaphor applied to religious texts", pp. 20-21; available at:

http://www.metaphorik.de/sites/www.metaphorik.de/files/journal-pdf/02_2002_jaekel.pdf

Johnson, Mark 1993. Moral Imagination: Implications of Cognitive Science for Ethics. Chicago/London: University of Chicago Press. https://doi.org/10.7208/chicago/9780226223230.001.0001

Kaufmann, Arthur. 1966. "Analogy and "the nature of things"; A contribution to the theory of types". Journal of the Indian Law Institute, Vol. 6, pp. 358-401.

Kövecses, Zoltán. 2000. Metaphor and Emotion: Language, Culture, and Body in Human Feeling. Cambridge: Cambridge University Press. 
Kövecses, Zoltán. 2015. Where Metaphors Come From: Reconsidering Context in Metaphor. Oxford: Oxford University Press. https://doi.org/10.1093/acprof:oso/9780190224868.001.0001

Lakoff, George 1987: Women, Fire and Dangerous Things: What Categories Reveal about the Mind. Chicago: University of Chicago Press. https://doi.org/10.7208/chicago/9780226471013.001.0001

Lakoff, George \& Mark Johnson. 1980/2003 (2nd ed.) Metaphors We Live By. Chicago: University of Chicago Press. https://doi.org/10.7208/chicago/9780226471013.001.0001

Lakoff, George \& Mark Johnson. 1999. Philosophy in the Flesh. New York: Basic Books.

Lakoff, George \& Rafael E. Núñez. 2000. Where Mathematics Comes From: How the Embodied Mind Brings Mathematics into Being. New York: Basic Books.

Lakoff, George \& Mark Turner. 1989. More than Cool Reason: A Field Guide to Poetic Metaphor. Chicago: University of Chicago Press. https://doi.org/10.7208/chicago/9780226470986.001.0001

Larsson, Stefan. 2011. Metaphors and Norms: Understanding Copyright Law in a Digital Society. Lund: Lund University.

Machery, E. 2005. "Concepts are not a natural kind". Philosophy of Science 72, 444-67. https://doi.org/10.1086/498473

Mellinkoff, David. 1963. The Language of the Law. Boston: Little, Brown and Co.

Morawski, Lech. 2002. Wyktadnia w orzecznictwie sąów. Komentarz. Torun.

Radecki, Wojciech. 1972. "Przestępstwa przeciwko wolności w sferze życia seksualnego" [Offences against freedom in sexual life], Vol. II, Prob. Praw. 1972, no. 5-6.

Stępień, K. 2000. Szczególne okrucieństwo jako znamię kwalifikowanego typu przestępstwa zgwałcenia, Przegląd Sądowy, no. 10 \& Gdansk Appelate Court's verdict of 25 January 2001, II AKa 382/00, Prokuratura i Prawo 2001, no. 11.

Sweetser, Eve. 1990. From Etymology to Pragmatics: Metaphorical and cultural aspects of semantic structure. Cambridge \& New York: Cambridge University Press. https://doi.org/10.1017/CBO9780511620904

Sweetser, Eve. 2001. "Blended spaces and performativity". Cognitive Linguistics, 11(3/4), 305334. https://doi.org/10.1515//ogl.2001.018

Taub, Sarah F. 2001. Language from the Body: Iconicity and Metaphor in American Sign Language. Cambridge: Cambridge University Press. https://doi.org/10.1017/CBO9780511509629

Turner, Mark. 1987. Death is the Mother of Beauty: Mind, Metaphor, Criticism. Chicago: University of Chicago Press.

Turner, Mark. 2006. The Artful Mind: Cognitive Science and the Riddle of Human Creativity. Oxford: Oxford University Press.

Williams, Christopher. 2005. Tradition and Change in Legal English: Verbal Constructions in Prescriptive Texts. Bern: Peter Lang.

Witczak-Plisiecka, Iwona. 2013. "Speech action in legal contexts". In Marina Sbisà \& K. Turner (eds.), Pragmatics of Speech Actions [Handbook of pragmatics; Part 2], Berlin/Boston: Mouton de Gruyter, pp. 613-658.

Witczak-Plisiecka, Iwona. 2007. "Linguistic aspects of the deontic shall in the legal context" In Kredens K. \& Stanisaw Goźdź-Roszkowski. (eds.) Language and the Law: International Outlooks. Frankfurt: Peter Lang, pp. 181-199.

Witczak-Plisiecka, Iwona. 2008. "The relevance of vague expressions in legal language". Research in Language, Vol. 6, pp. 165-186.

Wojtczak, Sylwia, Iwona Witczak-Plisiecka, Rafał Augustyn. 2017. Metafory konceptualne jako narzędzia rozumowania i poznania prawniczego [Conceptual Metaphors as Tools in Legal Reasoning and Cognition]. Warszawa: Wolters Kluwer.

Wróblewski, Jerzy, 1948. Język prawny i prawniczy. Kraków: Polska Akademia Umiejętności.

Wróblewski, Jerzy. 1959. Zagadnienia teorii wyktadni prawa ludowego. Warszawa.

Wróblewski, Jerzy. 1984. "Zagadnienia terminologii nauk prawnych" [Terminology issues in legal sciences]. Nauka Polska 3, pp. 80-82. 